
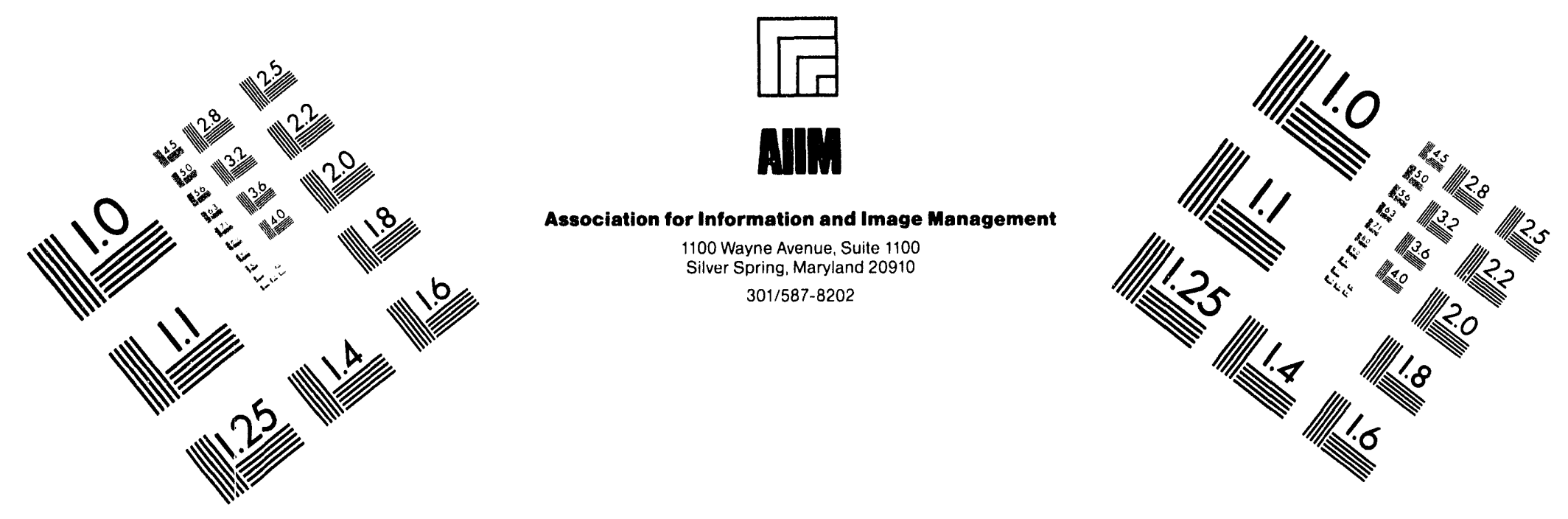

\title{
Centimeter
}

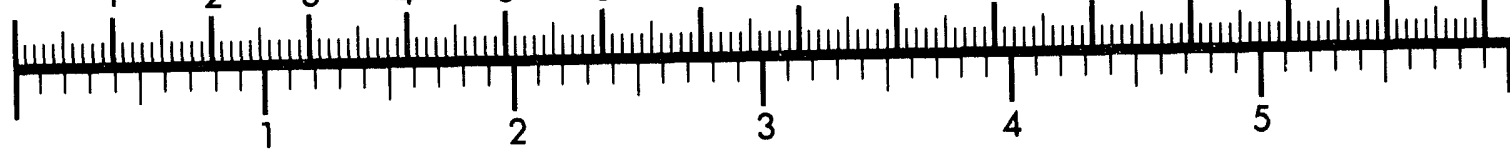
Inches
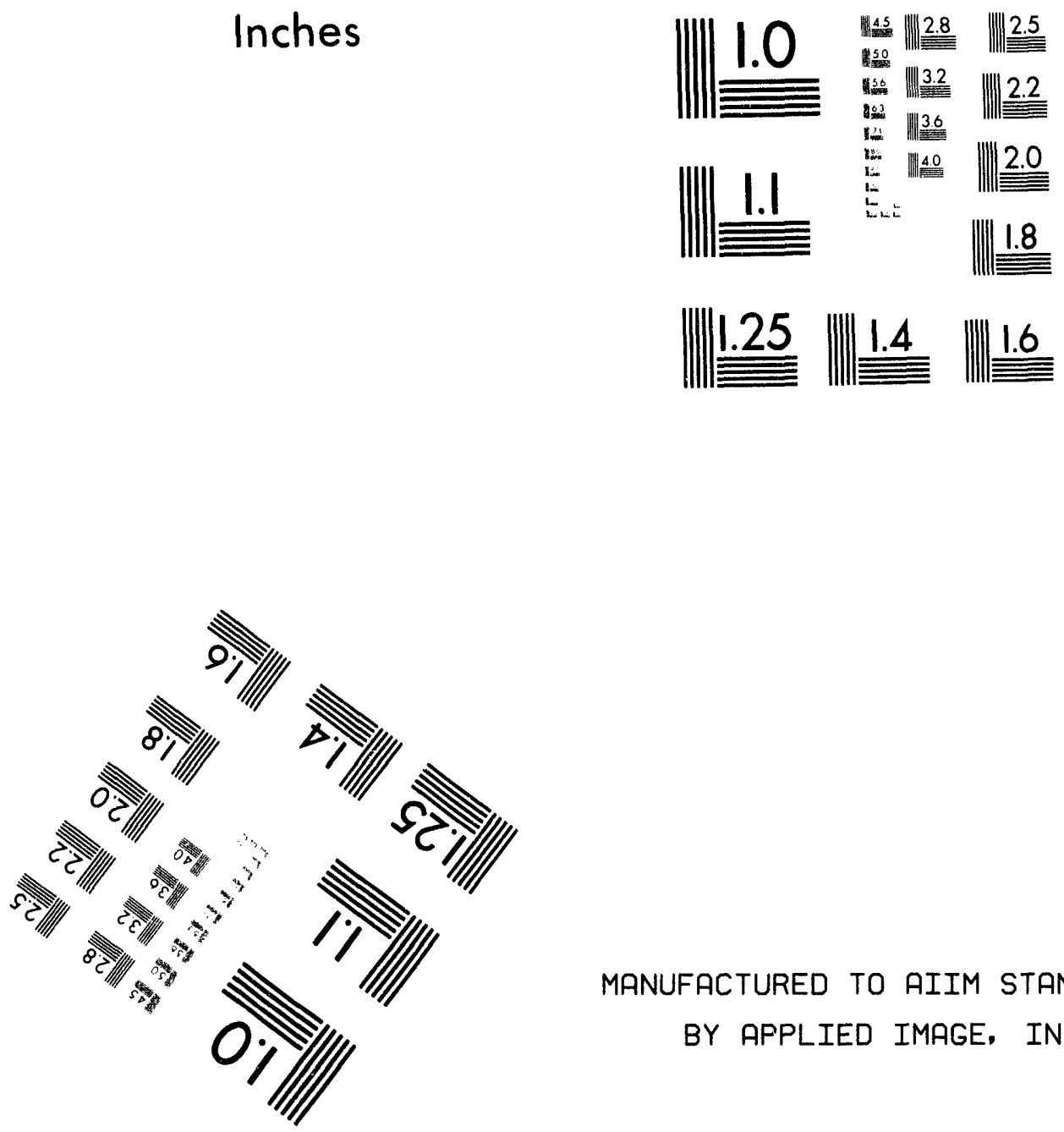

MANUFACTURED TO AIIM STANDARDS

$$
\text { BY APPLIED IMAGE, INC. }
$$

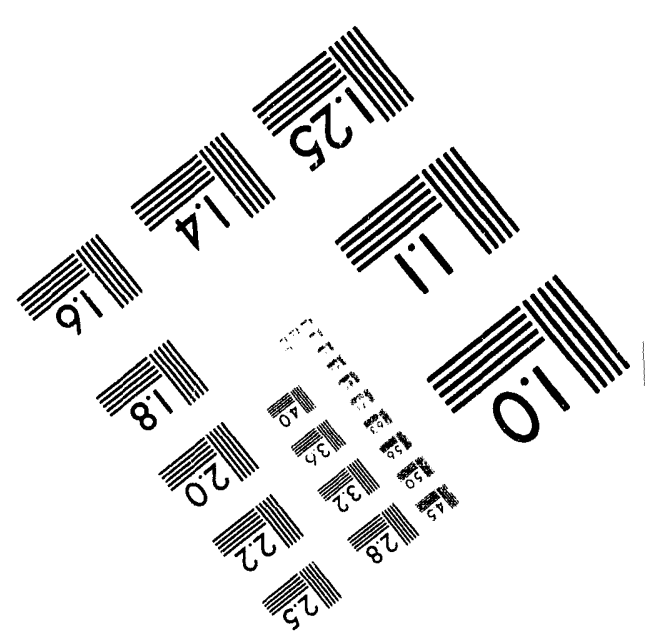



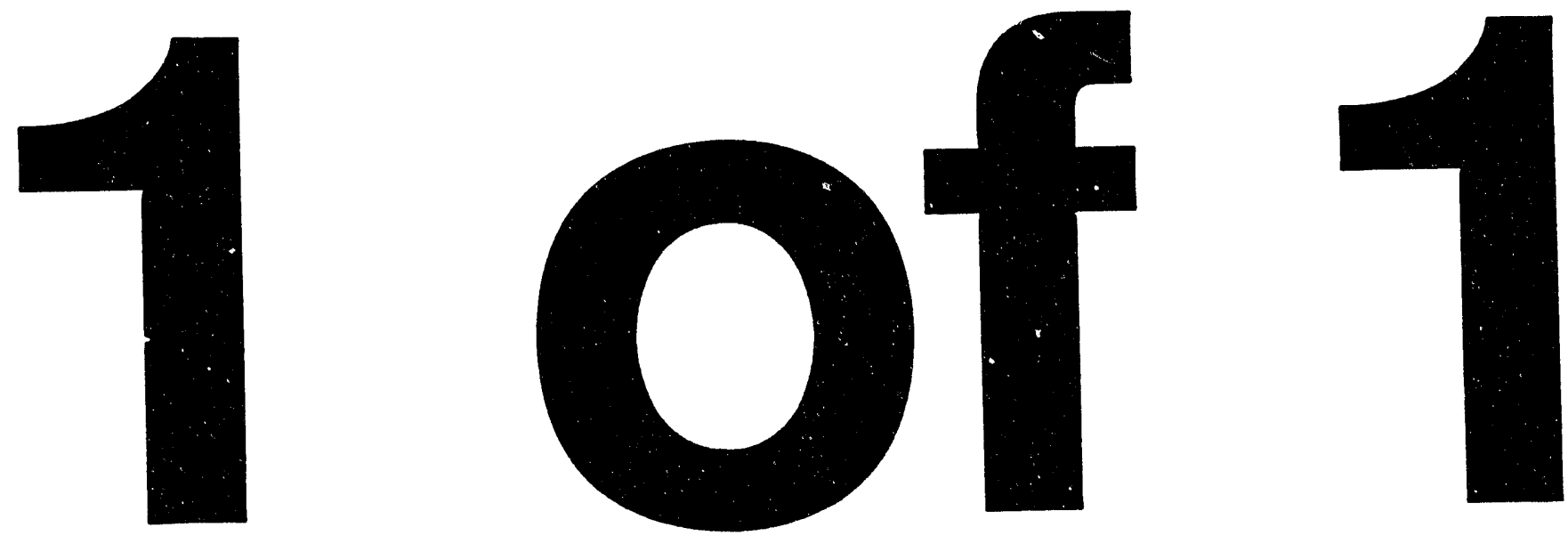


\section{NUCLEAR CRITICALITY SAFETY EVALUATION OF THE PASSAGE OF DECONTAMINATED SALT SOLUTION FROM THE ITP FILTERS INTO TANK 5OH FOR INTERIM} STORAGE.

by

Hobbs, D. T.

Westinghouse Savannah River Company

Savannah River Site

Aiken, South Carolina 29808

This paper was prepared in connection with work done under the above contract number with the U.S. Department of Energy. By acceptance of this paper, the publisher and/or recipient acknowledges the U.S. Government's right to retain a nonexclusive, royalty-free license in and to any copyright covering this paper, along with the right to reproduce and to authorize others to reproduce all or part of the copyrighted paper.

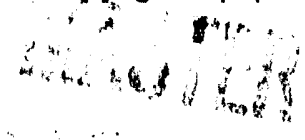




\section{DISCLAIMER}

This report was prepared as an account of work sponsored by an agency of the United States Government. Neither the United States Government nor any agency thereof, nor any of their employees, makes any warranty. express or implied. or assumes any legal liability or responsibility for the accuracy. completeness, or usefulness of any information. apparatus, product, or process disclosed, or represents that its use would not iafringe privately owaed rights. Refereace hereia to any specific commercial product, process, or service by trade name, trademark. manufacturer, or otherwise does not necessarily constitute or imply its endorsement, recommendation, or favoring by the United States Governmeat or any ageacy thereof. The views, and opinions of authors expressed berein do not necessarily state or reflect those of the United States Government or any agency ithereof.

This report has been reproduced directly from the best available copy.

Available to DOE and DOE coneractors from the Office of Scieatific and Technical Lnformation. P. O. Box 62. Oak Ridge. TN 37831: prices available from (615) $576-8401$.

Available to the public from the National Techaical Information Service. U. S. Deparment of Commerce, 5285 Por Royal Rd. Springfield. VA 22161 
Keywords: Solubility, Uranium, Plutonium, Solids, Precipitate, Crystallize

Rstention: permanent

\section{NCSE WM 94-2}

Nuclear Criticality Safety Evaluation of the Passage 'f Decontaminated Salt Solution from the ITP Filters into Tank 50H for interim Storage (U)

by

D. T. Hobbs

J. R. Davis

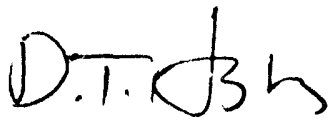

D. T. Hobbs

$$
6-9-94
$$
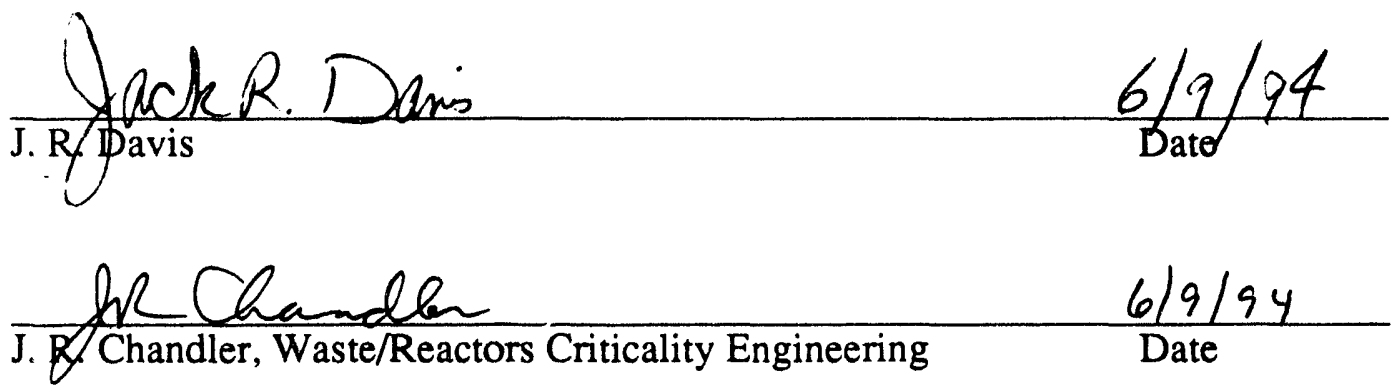

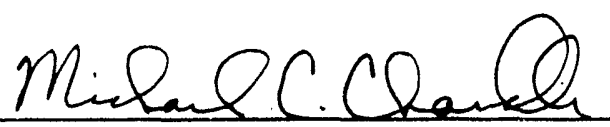

M. C. Chandler, Manager, HLWE Waste Characterization

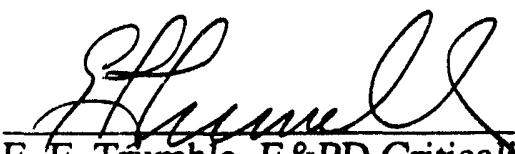

E.F. Trumble, E\&PD Criticaly Technology

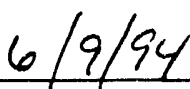


WSRC-TR-94-0269

Rev. 0

page - 2 -

\subsection{Introduction}

This report assesses the nuclear criticality safety associated with the decontaminated salt solution after passing through the In-Tank Precipication (ITP) filters, through the stripper columns and into Tank $50 \mathrm{H}$ for interim storage until transfer to the Saltstone facility (shaded region in Figure 1). This report does not address criticality safety of the ITP process carried out in Tank $48 \mathrm{H}$, the storage of precipitate slurry in Tank $49 \mathrm{H}$, the washing of the precipitate, storage of spent wash water in Tank $22 \mathrm{H}$, or the Late Wash Facility. The criticality safety basis for the ITP process is documented in references 1-3.

\subsection{Summary}

Criticality safety in the ITP filtrate has been analyzed under normal and process upset conditions. This report evaluates the potential for criticality due to the precipitation or cystallization of fissionable material from solution and an ITP process filter failure in which insoluble material carryover from salt dissolution is present. It is concluded that no single inadvertent error will cause criticality and that the process will remain subcritical under normal and credible abnormal conditions.

\subsection{Description}

Redissolved salt solution will be treated with sodium tetraphenylborate and monosodium titanate (MST) in the ITP process to remove cesium, strontium, and actinides (see Figure 1 for flow diagram). The cesium and potassium in the salt solution precipitate as tetraphenylborate salts. Strontium, uranium and plutonium are adsorbed by the MST solids. The highly radioactive solids are separated from the decontaminated salt solution by filtration. The solids will be sent to the DWPF for vitrification. The decontaminated salt solution will be transferred to the Saltstone facility for incorporation into a cementitous wasteform.

In the filtration process, the precipitate slurry is pumped from Tank $48 \mathrm{H}$ through a porous sintered-metal tube. The salt solution passes through the sintered-metal filter into the shell-side of the filter assembly. The solids are swept along the filter and returned to Tank $48 \mathrm{H}$. The filter is designed to have a very high efficiency for particle retention $(\geq 99.998 \%)$ in order to meet the decontamination factor requirement for the removal of ${ }^{137} \mathrm{Cs}$. Thus, there will be only a very small amount of precipitate solids that will pass through the filter into the filtrate during normal operations. Section 6.6 of this report analyzes the impact of a filter failure resulting in the carryover of solids with the filtrate.

From the filter assembly, the salt solution is transported to one of two stripper columns where it is contacted with humidified nitrogen to remove benzene. Prior to the stripper columns, tri-n-butyl phosphate (TBP) is added to the salt solution to minimize foaming during the stripping stage. After the stripper, the decontaminated salt solution is collected in one of two filtrate hold tanks for a short period of time (design time is 2 hours) to confirm that the radioactive content meets Saltstone feed requirements.

If the solution meets the requirements, it is pumped to Tank $50 \mathrm{H}$ and stored prior to transfer to Saltstone. If the solution does not meet the requirements it is returned to Tank $48 \mathrm{H}$ for reprocessing in the ITP process. During storage in Tank $50 \mathrm{H}$, the decontaminated salt solution is mixed with concentrate from the Effluent Treatment Facility (ETF). Corrosion inhibitors, sodium hydroxide and sodium nitrite, may be added during storage if analysis of solution samples indicates that there is not sufficient corrosion inhibitors present. The corrosion inhibitors are added as concentrated solutions. 
WSRC-TR-94-0269

Rev. 0

page - 3 -

Figure 1. In-Tank Precipitation Process Flow Diagram

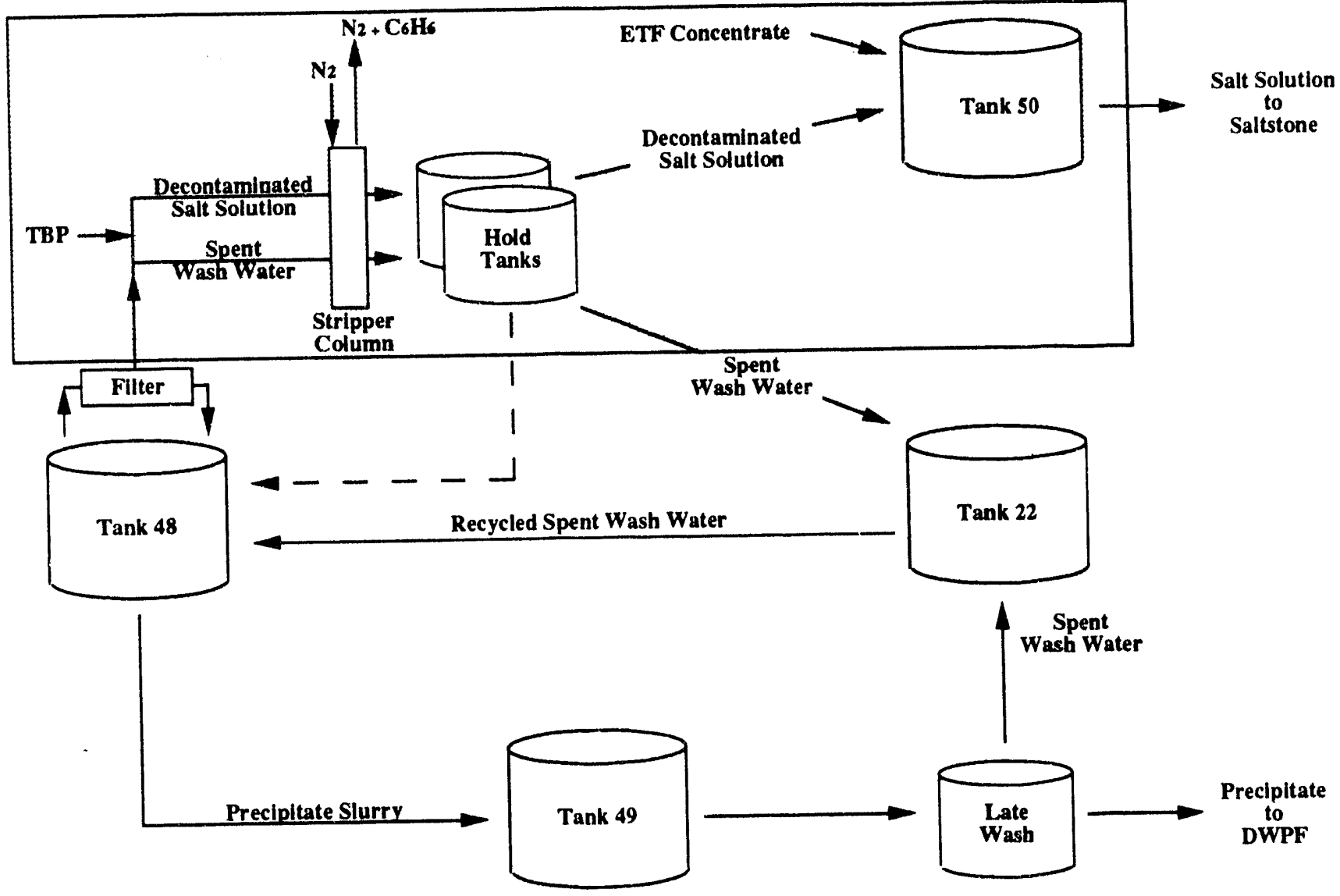

\subsection{Requirements Documentation}

Documentation of the presence of filtrate solution containing concentrations of uranium and plutonium in the ITP filtrate process is governed by the requirements given in the SRS Criticality Safety Manual[4]. This evaluation is completed in accordance with that manual and with DOE-STD-3007-93, "Guidelines for Preparing Criticality Safety

Evaluations at Department of Energy Non-Reactor Nuclear Facilities"[5]. This NCSE establishes upper bounding conditions. It does not attempt to establish operating limits. Appropriate consideration to additional margins of safety should be incorporated during the development of operating procedures to protect against uncertainties in process variables and against a limit being accidentally exceeded. 
WSRC-TR-94-0269

Rev. 0

page - 4 -

\subsection{Methodology}

During normal operation, the maximum concentration of uranium and plutonium is expected to be very low. To assure criticality safety for non-process upset conditions, an evaluation of possible changes in the chemistry of the salt solution was made. If the material can be shown to remain as a uniform aqueous solution, then the limits of reference 6 apply, and hence, the operation is shown to be safe from an unplanned criticality.

To use the single-parameter limit of concentration for an unlimited volume, it is implied that the concentrations of the saturated solutions are not exceeded. Additionally, a limit must be appilied to the mixture of fissile nuclides in which all components of the mixture are to be considered as the one with the most restrictive limit. Therefore, since the filtrate solution contains both uranium and plutonium, the more restrictive plutonium concentration of $7.3 \mathrm{~g} / \mathrm{L}$ will be used. Further, this limit applies to mixtures of plutonium isotopes provided the concentration of ${ }^{240} \mathrm{Pu}$ exceeds that of ${ }^{241} \mathrm{Pu}$ and provided ${ }^{241} \mathrm{Pu}$ is considered to be ${ }^{239} \mathrm{Pu}$ in computing concentration.

For the process of interest, the above condition is valid [2,3]. All fissionable material evaluated has been assumed to be $100 \%{ }^{235} \mathrm{U}$ and $100 \%{ }^{239} \mathrm{Pu}$. Each stage of the process from filtration through the stripper columns, through the filtrate hold tanks, and on into the $50 \mathrm{H}$ storage tank will be independently evaluated below for suitability to the limits stated. The maximum bounding concentrations entering the ITP process are $1.68 \mathrm{mg} / \mathrm{L}$ plutonium and $17.1 \mathrm{mg} / \mathrm{L}$ uranium. Assuming all of the fissionable material to be plutonium, the maximum bounding concentration is $18.8 \mathrm{mg} / \mathrm{L}$, which is only $0.26 \%$ of the allowed limit [6]. Although the actual concentrations of uranium and plutonium on the filtrate side will be much lower during normal operation, these numbers were conservatively established to account for any uncertainties in process variables.

For the process upset condition, the only credible failure that could impact the filtrate treatment process would be filter degradation in which insoluble material carryover from salt dissolution or fissile-material-laden MST may enter the filtrate processing side. An evaluation of possible criticality implications of this failure has been based upon the analyses in references 2 and 3 . The process impact is discussed under a separate section (6.6) later in the analysis.

\subsection{Discussion of Contingencies}

As shown in section 6.0, this system will remain subcritical under any combination of credible upset conditions. Therefore, no discussion of contingencies is applicable.

\subsection{Evaluation and Results}

\subsection{Concentration of Uranium and Plutonium in Filtrate}

Upon redissolution of saltcake for processing in the ITP process, the concentration of uranium and plutonium could reach saturation since there is a sufficient quantity of undissolved uranium and plutonium in sludge solids. However, the concentration of uranium and plutonium is decreased during the ITP process by the addition of dilution water. Thus, the decontaminated salt solution will not be at the solubility limit for either uranium and plutonium as it passes through the sintered-metal filter. The concentration of uranium and plutonium is also reduced upon the addition of monosodium titanate. However, since MST will not always be added during the ITP process, no allowance for the removal of uranium and plutonium by adsorption onto MST is considered in this evaluation. 
Rev. 0

page - 5 -

The solubilities of uranium and plutonium in alkaline salt soiutions over the range of compositions expected to occur during the ITP process has been studied [7]. The maximum concentration was determined to be $17.1 \mathrm{mg} / \mathrm{L}$ for uranium and $1.68 \mathrm{mg} / \mathrm{L}$ for plutonium. The redissolved salt solution transferred into the Tank $48 \mathrm{H}$, will have on average a sodium ion concentration of 6.30 molar. Dilution water and reagent chemicals will be added during the ITP process that will reduce the sodium ion concentration to $5.16 \mathrm{M}[8]$. Thus, the uranium and plutonium concentrations will be diluted by a factor of 1.22 , resulting in a maximum uranium concentration of $14.0 \mathrm{mg} / \mathrm{L}$ and plutonium concentration of $1.38 \mathrm{mg} / \mathrm{L}$ in the decontaminated salt solution that will pass through the sintered-metal filter.

\subsection{Addition of Tri-n-Butyl Phosphate to the Filtrate}

Prior to the stripper columns, TBP will be added to the decontaminated salt solution to provide a concentration of about $50 \mathrm{ppm}$. Since TBP and its degradation products, di-nbutyl phosphate (DBP) and mono-n-butyl phosphate (MBP), are known to form complexes with uranium and plutonium in nitric acid solutions, there is the potential for the compounds to alter the chemical behavior of uranium and plutonium in alkaline salt solutions. Studies have shown that the addition of TBP, DBP, and MBP at concentrations of up to $33 \%$ by volume do not affect the chemical behavior of uranium and plutonium in alkaline salt solutions [9]. The solubility of uranium was not lowered upon addition of any of the alkylphoshate, uranium was not extracted in a separate TBP phase, and the addition of the alklyphosphates did not produce a separate solid phase. Thus, the addition of normal amounts $(50 \mathrm{ppm})$ or unexpectedly high amounts of TBP due to a process upset will not result in the precipitation or crystallization of fissile materials or the formation of a second liquid phase containing fissile materials at any time during the process.

\subsection{Stripper Columns}

The decontaminated salt solution is passed through one of two stripper colums to remove benzene. The benzene is stripped using humidified nitrogen. The nitrogen is humidifed to minimize the evaporation of water that could result in concentration of the salt solution. In the event that the nitrogen was not saturated with water before contacting the salt solution, some evaporation of the solution could occur resulting in the concentration of the salt solution. As a result of the concentration, uranium and/or plutonium could crystallize from the solution if the solublility limits of either or both were exceeded.

The maximum amount of evaporation that could occur would be the amount of water that would present in the nitrogen at saturation. At $35^{\circ} \mathrm{C}$, the amount of water required to saturate nitrogen at a flowrate of $440 \mathrm{scfm}$ is calculated to be $564 \mathrm{~g} / \mathrm{min}$ [10]. The design liquid feed rate to the strippers is $120 \mathrm{gal} / \mathrm{min}$. Assuming that the lowest attainment for feed to the stripper columns is $5 \mathrm{gal} / \mathrm{min}$ or $4.2 \%$ of the design rate, then the maxinum volume decrease due to evaporation is calculated to be $2.9 \%$ by volume. Thus, the maximum concentration is a factor of six less than the dilution of uranium and plutorium from their solubility limits (18\%) resulting from the addition of dilution water in Tank $48 \mathrm{H}$. Therefore, the uranium and plutonium concentrations cannot exceed the solubility limits and solids will not form due to evaporation in the stripper columns.

\subsection{Filtrate Hold Tanks}

After the stripper columns, the salt solution is collected in one of two filtrate hold tanks. The solution is analyzed to confirm that the radioactivity does not exceed Saltstone feed specifications. There are no chemical additions made to the solution while stored in these tanks. Thus, the precipitation of uranium and/or plutonium will not occur as a result of changes in the chemical composition. 
WSRC-TR-94-0269

Rev. 0

page - 6 -

The storage time in these tanks is typically no more than 8 hours, although it could be longer if the process is stopped. Upon extended storage in the filtrate hold tanks, cooling of the solution could occur. However, for concentrated salt solutions the solubility of uranium increases slightly with decreasing temperature [11]. Over the temperature range from $25^{\circ}$ to $60^{\circ} \mathrm{C}$, the solubility of plutonium was not significantly affected by the temperature [7]. Thus, crystallization of uranium and/or plutonium will not occur in the event that the solution is cooled while stored in the filtrate hold tanks.

\subsection{Tank $50 \mathrm{H}$}

From the filtrate hold tank, the decontaminated salt solution is pumped to Tank $50 \mathrm{H}$ where it is stored until transferred to the Saltstone facility. While in Tank $50 \mathrm{H}$, the decontaminated salt sclution will be mixed with neutralized evaporated concentrate from the Effluent Treatment Facility. Also, corrosion inhibitors could be added to the tank in the event that either the hydroxide or nitrite concentrations do not meet the safety requirements[12].

The ETF concentrate is a salt solution similar to that of the decontaminated salt solution. Actinide concentrations in this stream are very low since the primary sources from which this stream is produced include evaporator overheads, storm runoff, and other miscellaneous process waters. To assess whether the mixing of the two waste streams could result in the formation of uranium or plutonium solids, the plutonium and uranium concentrations resulting from mixtures were compared to predicted solubilities.

During operations, ITP will produce $3.0 \times 10^{6}$ liters of decontaminated salt solution per batch with up to nine batches being produced per year. The ETF can produce up to $3.8 \times 10^{6}$ liters per year. However, the average annual production since startup of the ETF in 1988 has been $2.19 \times 10^{5}$ liters per year. Assuming that the number of batches of decontaminated salt solution ranges from at least one per year to a maximum of nine per year, then the volume ratios for mixtures of decontaminated supernate and ETF concentrate will range from 13.7:1 to 123:1. The capacity of the ITP filtrate hold tank is 45,000 liters $(12,000 \mathrm{gal})$. The capacity of the ETF concentrate hold tank is 7600 liter $(2000 \mathrm{gal})$. Thus, if both tanks were to be transferred to Tank $50 \mathrm{H}$ at the same time and location, the volume ratio upon mixing would be $6: 1$.

In the event that ITP shuc down for an extended period of time while ETF continued to operate and transferred concentrate to Tank $50 \mathrm{H}$, then the ratio of decontaminated salt solution to ETF concentrate upon restart of ITP would be considerably different than when both facilities are operating. For this case, a bounding volume ratio of 1:100 for decontaminated salt solution to ETF concentrate was selected. This ratio is equivalent to the addition of one transfer of decontaminated salt solution from the ITP hold tank $(45,000 \mathrm{~L})$ to Tank $50 \mathrm{H}$ filled with ETF concentrate $\left(4.5 \times 10^{6} \mathrm{~L}\right)$. Using these ratios as bounding mixing ratios, predicted solubilities were compared with concentrations for two cases: (1) uranium and plutonium concentrations in decontaminated salt solution reduced from saturation by dilution in ITP and no uranium and plutonium in the ETF concentrate, and (2) same as in (1) except the ETF concentrate is saturated in both uranium and plutonium.

Table 6.5.1 shows the predicted solubilities and the concentrations for the two cases over the range of mixtures described above. All of the calculated uranium and plutonium concentrations are at or below the predicted solubilities for the mixtures of decontaminated salt solution and the ETF concentrate stream. Therefore, it is concluded 
WSR.C-TR-94-0269

Rev. 0

page - 7 -

that during normal operations and aftei resumption of the ITP process after an extended shutclown, precipitation of uranium and plutonium will not occur upon mixing the two waste streams in Tank $50 \mathrm{H}$.

Table 6.5.1 Uranium and Plutonium Concentrations and Predicted Solubilities for Salt Solutions Stored in Tank 50H

Uranium Concentration ( $\mathrm{mg} / \mathrm{L}$ )

\begin{tabular}{cccc} 
Mixture Ratio & Predicted Solubility & Case 1 & Case 2 \\
\hline $123: 1$ & 7.60 & 5.77 & 5.88 \\
$82: 1$ & 7.61 & 5.74 & 5.88 \\
$27: 1$ & 7.65 & 5.61 & 5.88 \\
$14: 1$ & 7.71 & 5.42 & 5.88 \\
$6: 1$ & 7.85 & 5.05 & 6.49 \\
$1: 1$ & 8.44 & 3.11 & 5.99 \\
$1: 5$ & 8.79 & 1.04 & 5.84 \\
$1: 20$ & 8.28 & 0.30 & 5.78 \\
$1: 100$ & 7.07 & 0.062 & 5.76 \\
& & & \\
& & & \\
Mixture Ratio & Predicted Solubility & Case 1 & Case 2 \\
$123: 1$ & 0.11 & 0.081 & 0.083 \\
$82: 1$ & 0.11 & 0.080 & 0.083 \\
$27: 1$ & 0.11 & 0.078 & 0.083 \\
$14: 1$ & 0.11 & 0.076 & 0.083 \\
$6: 1$ & 0.11 & 0.070 & 0.090 \\
$1: 1$ & 0.11 & 0.045 & 0.10 \\
$1: 5$ & 0.12 & 0.015 & 0.11 \\
$1: 20$ & 0.12 & 0.004 & 0.12 \\
$1: 100$ & 0.12 & 0.001 & 0.12 \\
& & & \\
& & &
\end{tabular}

Mixture Ratio is the ratio of the volume of decontaminated salt solution to the vo ume of ETF concentrate

Case 1: uranium and plutonium concentrations in decontaminated salt solution reouced from saturation by dilution in ITP plus no uranium and plutonium in the ETF concentrate

Case 2: uranium and plutonium concentrations in decontaminated salt solution reduced from saturation by minimal removal in ITP plus saturated uranium and plutonium concentrations in the ETF concentrate 
Rev. 0

page - 8 -

During the storage of the alkaline salt solutions in Tank $50 \mathrm{H}$, corrosion inhibitors may be added due to the depletion of hydroxide and/or nitrite. Thus, concentrated solutions of either sodium hydroxide ( $50 \mathrm{wt} \%$ ) or sodium nitrite $(40 \mathrm{wt} \%)$ will be added as necessary to increase the inhibitor concentrations to the required levels. This will have the effect of increasing the hydroxide or nitrite concentrations and diluting the other salt concentrations.

Tests have indicated that the solubility of plutonium increases with increasing hydroxide and nitrite concentrations if other salt component concentrations remain fixed $[7,13]$. Figures 1 and 2 show plots of the predicted plutonium solubilities as a function of hydroxide and nitrite concentrations for a solution having the average decontaminated salt solution composition. Since the solubility of plutonium increases with increases in both hydroxide and nitrite concentrations, addition of either sodium hydroxide or sodium nitrite solutions to Tank $50 \mathrm{H}$ will not result in the formation of plutonium solids.

Figure 3 shows a plot of the predicted uranium concentration versus nitrite concentration [11]. The uranium concentration inceases with increasing nitrite concentration. Thus, it is concluded that the addition of sodium nitrite to the decontaminated salt solution will not result in the formation of uranium solids.

For concentrated salt solutions, the solubility of uranium decreases with increasing hydroxide if other salt component concentrations remain fixed[11]. During storage of decontaminated salt solution, the hydroxide concentration will decrease and the carbonate concentration increase due to the absorption of atmospheric carbon dioxide. The predicted solubility of uranium increases with such a change in the solution phase chemistry. If the hydroxide concentration was to decrease such that additional sodium hydroxide was required to meet the operationa! safety requirements [12], the addition would not result in the formation of uranium solids since the solubility of the higher carbonate solution is greater than the original solution (see Table 6.5.2). 
WSRC-TR-94-0269

Rev. 0

page - 9 -

Figure 1. Solubility of Plutonium in Concentrated Salt Solution as a Function of Hydroxide Concentration

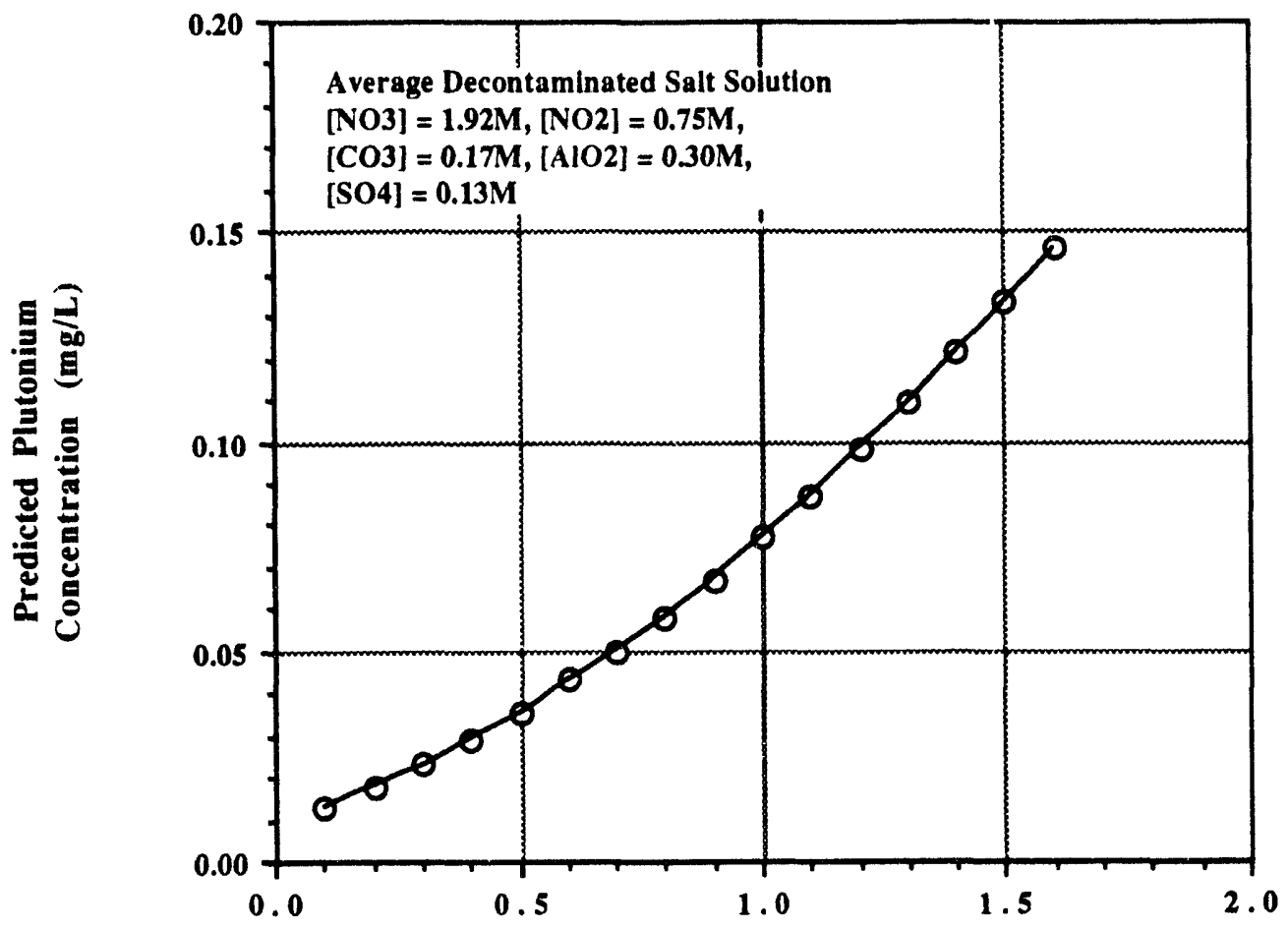

Hydroxide Concentration (M) 
WSRC-TR-94-0269

Rev. 0

page - 10 -

Figure 2. Solubility of Plutonium as a Function of Simuiataneous and Equal Increases in Hydroxide and Nitrite Concentrations

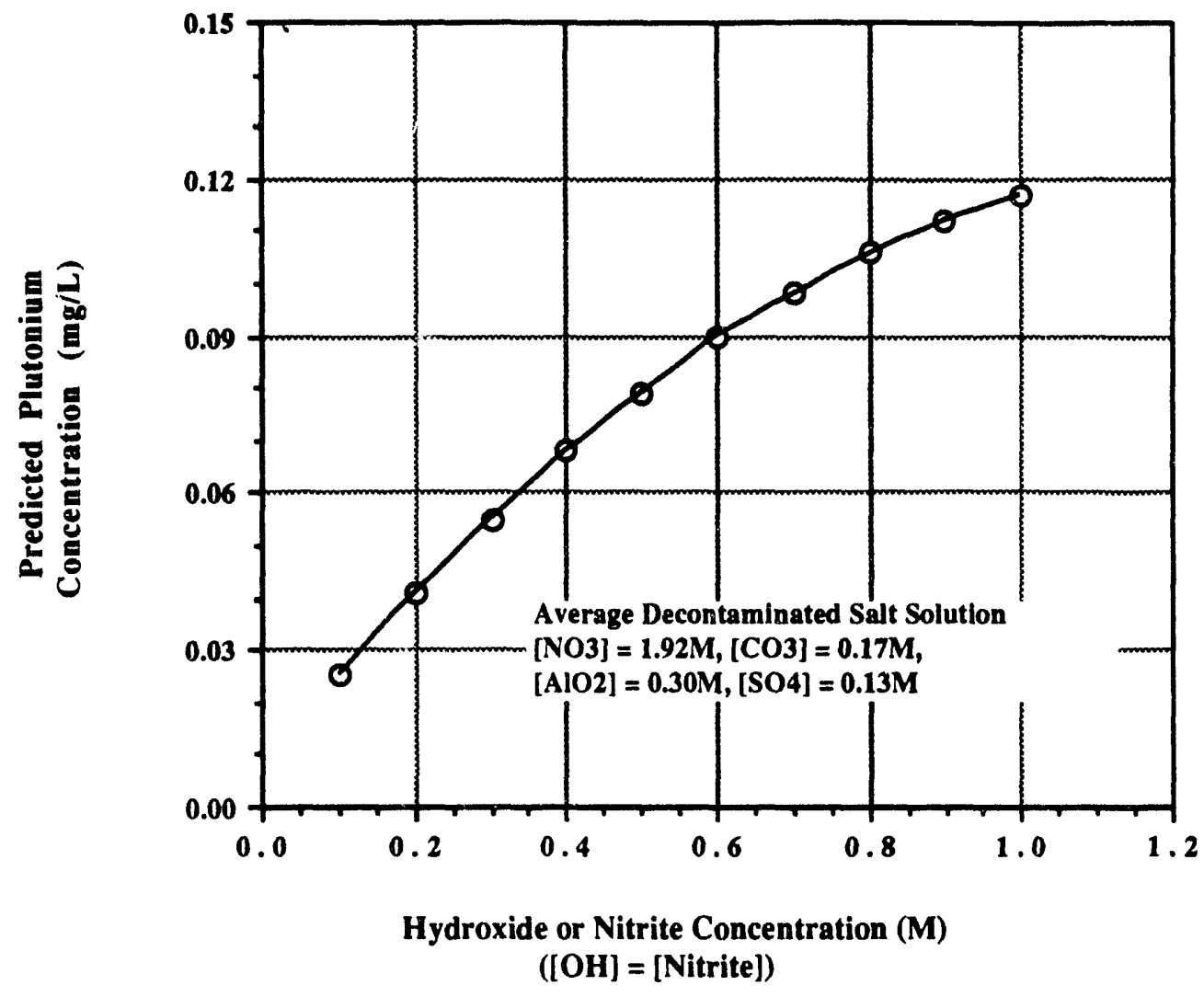


WSRC-TR-94-0269

Rev. 0

page - 11 -

Figure 3. Solubility of Uranium in Salt Solution as a Function of Nitrite Concentration

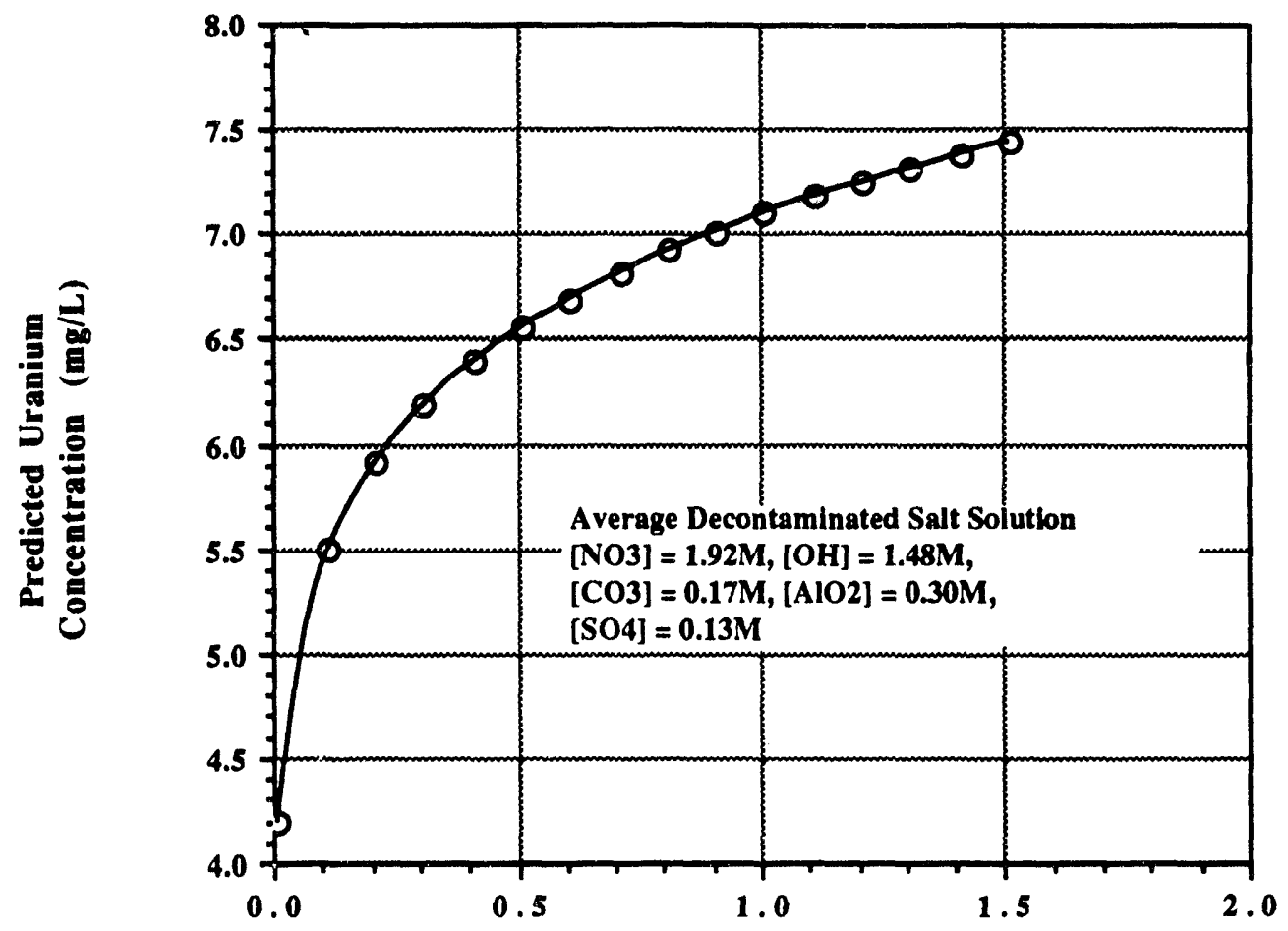

Nitrite Concentration (M)

Table 6.5.2 Solubility of Uranium Upon Absorption of Atmospheric Carbon Dioxide and Addition of Sodium Hydroxide

Stage

Original Solution

$\mathrm{CO} 2$ absorbed producing solution below OSR

$\mathrm{NaOH}$ added to raise hydroxide concentration
[Hydroxide] (M) [Carbonate] Predicted Solubilityb Solution OSR Rea. ${ }^{2}$ $>0.192$ (M)

$0.17-6.93$
mg/h)
0.148

$>0.192$

0.836

0.836

0.836

0.836

C.836

17.4

12.2

9.30

7.42

a Minimum hydroxide concentration required per Operational Safety Requirements (ref. 12)

b Reference 11 
Rev. 0

page - 12 -

\subsection{ITP Filter Degradation}

Degradation of the ITP filter does not represent a credible scenario for an unplanned criticality. The filter is constructed as a porous sintered-metal tube. There is no known method of destruction of this filter except possibly corrosion. However, if for some reason the filter began to degrade, it would allow the precipitate slurry to cross-over and enter the ITP Filtrate processing side.

The highest fissile material concentration that would enter the ITP process is $18.8 \mathrm{mg} / \mathrm{L}$ and is assumed to be ${ }^{239} \mathrm{Pu}$ [2]. This concentration is much lower than the maximum concentration allowed by reference 6 and consequently does not represent a concern. Nuclear criticality safety analysis calculations were performed for the precipitate slurry side to determine the safe bounding conditions for mixtures of MST and utilized the maximum solubilities for uranium and plutonium in the alkaline ITP solutions[2]. The analysis shows that, assuming $100 \%$ fissile isotopic content of uranium and plutonium a minimum of eight MST mass additions is required before sufficient mass can accumulate.

The anticipated process condition is to accumulate solids from six ITP process cycles. Certainly, a filter degradation will not result in a total mass transfer to the filtrate processing side of the ITP operation, and hence, the amount that may carry over from a process upset would be insignificant from a criticality standpoint. Even if a total mass transfer occurred, it would not be expected to be any different than the ITP precipitate slurry processing side.

\subsection{Design Features and Administratively Controlled Limits}

Although there are no criticality control requirements for the filtrate processing side of the ITP operation, process variables and actinide concentrations are moritored throughout processing and provide a confirmation of the safety basis established by this report. One particular monitoring hold-point, that of the high activity monitoring in the filtrate hold tanks, can prove very useful in determining filter degradation. If high activity is repeatedly monitored in these tanks, it is quite possible a degradation of the filter which separates the precipitate slurry from the filtrate solution has occurred.

\subsection{Conclusions}

The report demonstrates that the ITP filtrate is safe from an unplanned criticality. Under normal operation, only a fraction of the maximum allowable safe concentration is present in any portion of the process. No mechanisms were identified which would concentrate the solution or precipitate the dissolved fissile solids. Further analysis has shown that the process would be safe during an unexpected filter failure in which precipitate slurry would carry $r$ into the filtrate processing side. No criticality control requirements were identif however, process monitoring should be used to verify the safety margin established il. w.s report.

\subsection{References}

1. WME-HLE-930553, Nuclear Criticality Safety Analysis WM-93-1. Determination of the Safe Accumulated MST Mass Addition in the ITP Process (U), A. Q. Goslen and C. E. Bess, February, 1993.

2. WSRC-TR-93-171, Nuclear Criticality Safety Bounding Analysis for the In-Tank Precipitation Process (U), M. C. Chandler, March 12, 1993. 
WSRC-TR-94-0269

Rev. 0

page - 13 -

3. WSRC-TR-94-004, Nuclear Criticality Safety Bounding Analysis for the In- Tank Precinitation (ITP) Process. Impacted by Fissile Isotopic WVeight Fraction (U), $C$. E. Bess, Aprill 22, 1994.

4. WSRC-IM-93-13, WSRC Nuclear Criticality Safety Manual (U), Rev. 1, 7/1/93.

5. DOE-STD-3007:93, Guidelines for Preparing Criticality Safety Evaluations at Department of Energy Non-Reactor Nuclear Facilities, Rev. 0, November 1993.

6. ANSI/ANS 8.1, Nuclear Criticality Safety in Operations with Fissionable Materials Qutside Reactors, Revision of ANSI N16.1-1975, October 7, 1983.

7. WSK-TR-93-056, Solubility of Plutonium and Uranium in Alkaline Salt Solutions (U), D.T. Hobbs, T.B. Edwards, S.D. Fleischman, February 12, 1993.

8. WSRC-RP-89-1303, Material Mass Balance and Planned Operating Schedule for the In-Tank Process (U), D. D. Walker and B. A. Hamm, December 27, 1989.

9. WSRC-TR-94-0134, The Effects of Tri-n-Butvl Phosphate and Its Degradation Products. Di-n-Butyl Phosphate and Mono-n-Butyl Phosphate on the Solubility of Actinides in Alkaline Salt Solution Solution (U), D. T. Hobbs, March 4, 1994

10. WSRC-NB-93-260, pages 158-159, Nitrogen Humidification Calculation (I), R. F. Swingle, May 25, 1994.

11. WSRC-TR-93-454, Solubility of Uranium in Alkaline Salt Solutions (U), D. T. Hobbs and T. B. Edwards, March 29, 1994.

12. WSRC-RP-90-1124, Operational Safety Requirements In-Tank Precipitation. Process Savannah River Site (U), Rev. 3, August 1, 1993.

13. WSRC-TR-93-131, Solubility of Plutonium in Alkaline Salt Solutions (U) D. T. Hobbs and T. B. Edwards, February 26, 1993. 
WSRC-TR-94-0269

Rev. 0

page - 14 -

Distribution:

D. T. Hobbs, 773-A

J. R. Davis, 730-M

J. R. Chandler, 773-24A

M. C. Chandler, 703-H

E. F. Trumble, 786-1T

R. E. Croley, 241-120H

D. C. Wood, 706-21C

B. Shapiro, 992W-1

M. K. Gupta, 992W-1

W. E. Van Pelt, 241-152H

T. M. Monahon, 703-H

J. E. Marra, 703-H

C. E. Apperson, 773-24A

J. Mincey, 773-24A

W. L. Tamosaitis, 773-A

S. D. Fink, 773-A

IWT-LWP File

TIM

H.H.Elder, 704-S

N.H. Kuchn, 704-1T

B.C. Ha $1773-A$ 

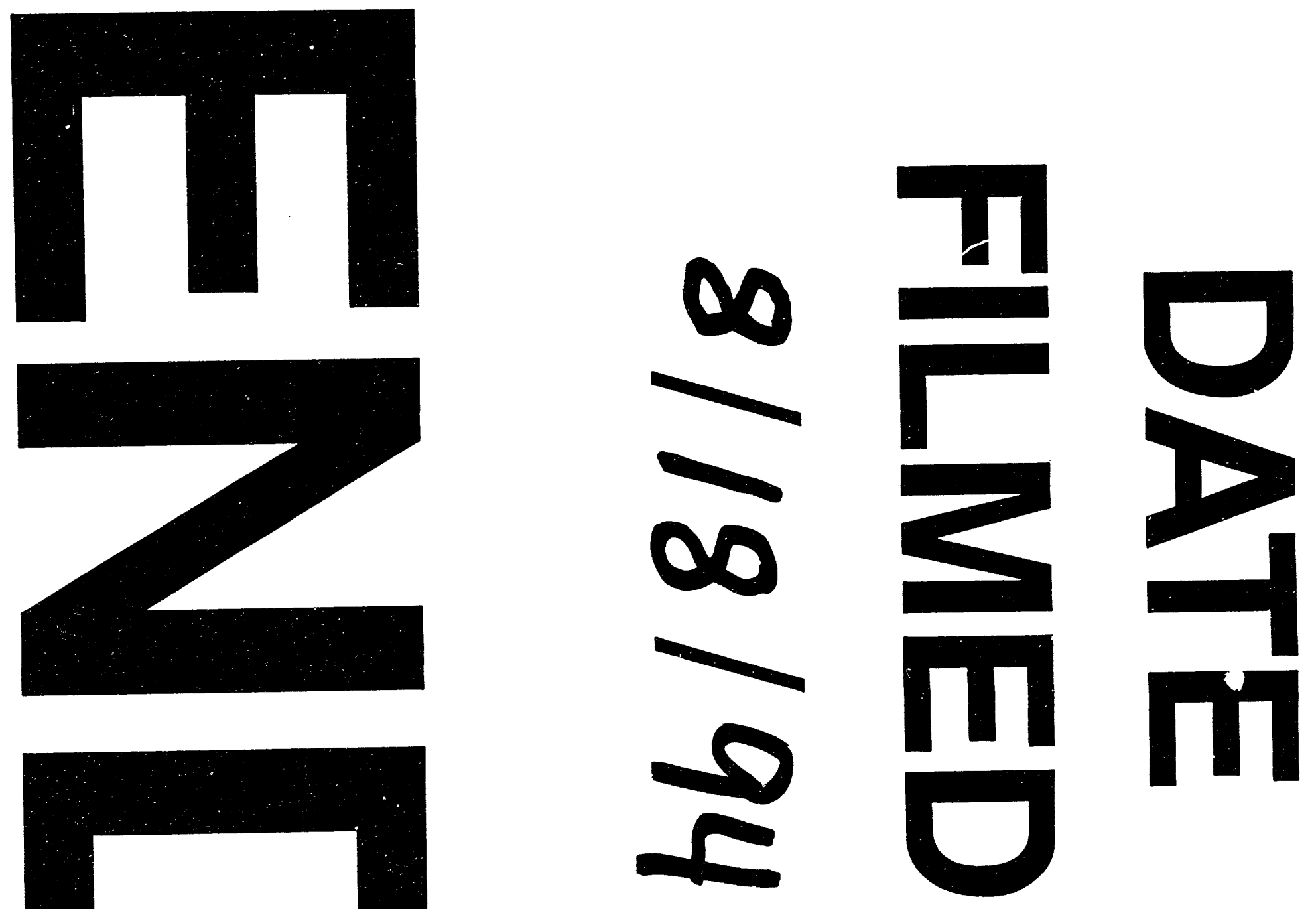
